\title{
GENETIC PARAMETERS FOR GROWTH TRAITS OF SANTA INES SHEEP USING GIBBS SAMPLING ${ }^{1}$
}

\author{
LEANDRO TEIXEIRA BARBOSA ${ }^{2 *}$, GLEICIANNY DE BRITO SANTOS ${ }^{2}$, EVANDRO NEVES MUNIZ ${ }^{3}$, \\ HYMERSON COSTA AZEVEDO ${ }^{3}$, JAILSON LARA FAGUNDES ${ }^{2}$
}

\begin{abstract}
This study sought to estimate (co)variance and genetic parameters for birth weight (BWT) and weaning weight (WWT) in Santa Ines sheep. A total of 2,111 records were obtained from EMBRAPA/CPATC experimental herds, dating from the years 1998 to 2008. (Co)variance parameters were obtained through a twotrait analysis with the Gibbs sampling algorithm using the MTGSAM program. The mixed model included the environmental effects of sex, contemporary group and type of birth, in addition to residual, direct and maternal additive effects. Mean estimates of direct heritability for BWT and WWT were 0.25 and 0.09 , respectively. Mean estimates of maternal heritability were 0.34 for BWT and 0.24 for WWT. The genetic correlation between BWT and WWT was 0.14. The results suggest that breeding Santa Ines sheep for meat production must take into consideration direct and maternal additive genetic effects.
\end{abstract}

Keywords: Bayesian analysis. Maternal effect. Birth weight. Weaning weight. High-density intervals.

\section{PARÂMETROS GENÉTICOS DAS CARACTERÍSTICAS DE CRESCIMENTO DE OVINOS SANTA INÊS USANDO AMOSTRADOR DE GIBBS ${ }^{1}$}

RESUMO - Objetivou-se neste estudo, estimar os componentes de (co)variância e parâmetros genéticos para as características de peso ao nascer (PN) e peso ao desmame ajustado aos 90 dias de idade (P90) em cordeiros da raça Santa Inês. Foram utilizados registro de 2.111 cordeiros obtidos de um rebanho experimental da EMBRAPA/CPATC, nascidos entre 1998 a 2008. Os componentes de (co)variância foram estimados pelo método de Amostrador de Gibbs por meio do programa Multiple Trait Gibbs Sampling for Animal Models (MTGSAM) em análise bicaracterística. No modelo misto foram incluídos os seguintes efeitos aleatórios: efeito genético aditivo direto, materno e efeito residual, além dos efeitos fixos de sexo, tipo de nascimento e grupo contemporâneo. A média da estimativa de herdabilidade aditiva direta para PN e P90 foram 0,25 e 0,09, respectivamente. A média da estimativa da herdabilidade materna foi de 0,34 para PN e 0,24 para P90, respectivamente. A correlação genética aditiva entre PN e P90 foi de 0,14. Os resultados sugerem que o melhoramento de ovinos Santa Inês para produção de carne deve levar em consideração os efeitos genéticos aditivos direto e materno.

Palavras-chave: Análise bayesiana . Efeito materno . Peso ao nascimento . Peso à desmama . Intervalo de alta densidade

\footnotetext{
*Corresponding Author

${ }^{1}$ Received for Publication in 24/03/2014; Accepted in 15/06/2015.

${ }^{2}$ Department of Zootechnology, UFS, Marechal Rondon Avenue, Rosa Elze, Zip Code 49100-000, São Cristovão, SE, Brazil; leandro@ufs.br, guegue_aju@hotmail.com, fagundes@ufs.br.

${ }^{3}$ Embrapa Tabuleiros Costeiros (CPATC), 3250 Beira Mar Avenue, Jardins, Mail Box 44, Zip Code 49025-040, Aracaju, SE. Brazil; evandro.muniz@embrapa.br,hymerson.azevedo@embrapa.br.
} 


\section{INTRODUCTION}

In Brazil, sheep meat production has been expanding due to the increasing consumption of sheep meat. Supermarkets and specialized restaurants have been forced to import sheep meat, primarily from Uruguay, to supply the increasingly demanding market (TORRES et al. 2009).

Body weight, measured throughout the growth period, is the most important piece of information for the genetic evaluation and selection of sheep for meat production. Weight at specific ages is associated with different traits that are generally correlated with one another; this factor makes it critical to know the magnitude and direction of such correlations, given that the selection of one trait could promote changes in other traits. Growth traits, such as birth weight and weaning weight, and the influence of maternal effects are important for determining the economic efficiency of any sheep production system (SOUSA, 1999). Genetic potential can thus be improved by using genetic evaluations for traits related to growth and subsequently selecting superior animals genetically and there is little information about it.

The genetic evaluation depends on the availability of accurate estimates of genetic parameters for the traits of interest. The accuracy of these parameter estimates depends on a number of factors, including the number of observations, the statistical model and the method for estimation of the (co)variance components (BARBOSA et al. 2008). Bayesian inference using Gibbs Sampling has become a good option for the evaluation of genetic merit because it reduces the number of biased estimates, even when there is little data available.

This study aimed to estimate the (co)variance components and genetic parameters for growth traits (i.e., birth weight and weaning weight) of Santa Ines sheep in a two-trait analysis using Bayesian Inference.

\section{MATERIALS AND METHODS}

This study used records obtained from 2,111 Santa Ines lambs (both sexes), born between 1998 and 2008, belonging to an experimental herd of the Brazilian Agricultural Research Organization (Empresa Brasileira de Pesquisa Agropecuária EMBRAPA Tabuleiros Costeiros), located in the town of Frei Paulo, in the semi-arid region of the State of Sergipe.

Birth weight (BWT) and weaning weight (WWT) were evaluated for growth traits. The weaning weight was adjusted to 90 days of age. Herd management practices were consistent throughout the data collection period.

The fixed effects considered were: sex, type of birth (i.e., single, twin and triplet) and contemporary group (defined by the combination of year and birth period). The birth periods were: JanuaryMarch, April-June, July-September, and OctoberDecember. Animals from quadruplet lambings were not included in the analysis due to the small number of such observations. In addition to fixed effects, the mixed model included random effects of direct and maternal additive genetic and residual:

$$
\mathbf{y}=\mathbf{X b}+\mathbf{Z}_{\mathbf{1}} \mathbf{d}+\mathbf{Z}_{\mathbf{2}} \mathbf{m}+\mathbf{e}
$$

where:

$\mathbf{y}$

$=$ vector of records;

$\mathbf{b}=$ fixed effects vector;

$\mathbf{X}$ = fixed effects incidence matrix;

$\mathbf{d}=$ direct additive genetic random effects vector;

$$
\mathbf{Z}_{1}=\text { direct additive genetic random effects }
$$
incidence matrix;

$\mathbf{m}=$ maternal additive genetic random effects vector;

$\mathbf{Z}_{\mathbf{2}}$ = maternal additive genetic random effects incidence matrix;

$\mathbf{e}=$ residual random effects vector.

To obtain the (co)variance components, Gibbs sampling was used in the Multiple Trait Gibbs Sampling for Animal Models (MTGSAM) program, described by Van Tassell and Van Vleck (1995).

Gibbs sampling is an indirect technique that generates random variables from a marginal distribution without having to calculate the marginal probability density function. Given the conditional distribution of data and a priori densities, the combined $a$ posteriori density of unknown parameters was calculated. Using this density, the conditional distribution of each variable was obtained, thus determining the remaining variables for the combined density. After marginal densities were established, basic statistics could be calculated for the a posteriori distributions (mean, mode and median).

The conditional distribution of $\boldsymbol{y}$ was assumed to be:

$$
\left(\mathbf{y} \mid \mathbf{b}, \mathbf{d}, \mathbf{m}, \sigma^{2}\right) \sim N\left[\mathbf{X b}+\mathbf{Z}_{\mathbf{1}} \mathbf{d}+\mathbf{Z}_{\mathbf{2}} \mathbf{m}, \mathbf{I}_{n} \sigma^{2}\right]
$$

The model assumed that: 


$$
\begin{aligned}
& E\left[\begin{array}{l}
y_{1} \\
y_{2}
\end{array}\right]=\left[\begin{array}{l}
X_{1} b \\
X_{2} b
\end{array}\right] \\
& \operatorname{Var}\left[\begin{array}{c}
d_{1} \\
m_{1} \\
e_{1} \\
d_{2} \\
m_{2} \\
e_{2}
\end{array}\right]=\left[\begin{array}{cccccc}
\mathbf{A} \sigma_{d_{1}}^{2} & \mathbf{A} \sigma_{d_{1} m_{1}} & 0 & \mathbf{A} \sigma_{d_{1} d_{2}} & \mathbf{A} \sigma_{d_{1} m_{2}} & 0 \\
\mathbf{A} \sigma_{d_{1} m_{1}} & \mathbf{A} \sigma_{m_{1}}^{2} & 0 & \mathbf{A} \sigma_{d_{2} m_{1}} & \mathbf{A} \sigma_{m_{1} m_{2}} & 0 \\
0 & 0 & \mathbf{I}_{\mathbf{N}} \sigma_{e_{1}}^{2} & 0 & 0 & \mathbf{I}_{\mathbf{N}} \sigma_{e_{1} e_{2}} \\
\mathbf{A} \sigma_{d_{1} d_{2}} & \mathbf{A} \sigma_{d_{2} m_{1}} & 0 & \mathbf{A} \sigma_{d_{2}}^{2} & \mathbf{A} \sigma_{d_{2} m_{2}} & 0 \\
\mathbf{A} \sigma_{d_{1} m_{2}} & \mathbf{A} \sigma_{m_{1} m_{2}} & 0 & \mathbf{A} \sigma_{d_{2} m_{2}} & \mathbf{A} \sigma_{m_{2}}^{2} & 0 \\
0 & 0 & \mathbf{I}_{\mathbf{N}} \sigma_{e_{1} e_{2}} & 0 & 0 & \mathbf{I}_{\mathbf{N}} \sigma_{e_{2}}^{2}
\end{array}\right]
\end{aligned}
$$

Where: A is the matrix containing numerators of Wright's coefficients of relationship between individuals (4019 animals); ${ }^{\sigma_{d_{i} d_{j}}}$ is the (co)variance between direct additive genetic effects for $i$ and $j$ traits; $\sigma_{m_{i} m_{j}}$ is the (co) variance between maternal additive genetic effects for $i$ and $j$ traits; $\sigma_{e_{i} e_{j}}$ is the (co)variance between residual effects for $i$ and $j$ traits, and when $i=j$, then these terms refer to the variances; and $\sigma_{d_{i} m_{j}}$ are the (co)variances between direct and maternal additive genetic effects for $i$ and $j$ traits.

The inverse Wishart distribution was used as the a priori distribution to estimate the (co)variance components, primarily due to computational efficiency, where an uninformative prior was utilized for all parameters analyzed. The Wishart density describes the distribution of the sum of squares and products for random variables that are normally distributed. Random effects were assumed to have a multivariate normal distribution, and the residual effects were assumed to be normally distributed.

Estimates of (co)variance components used in MTGSAM (threshold) were previously obtained by restricted maximum likelihood. The number of initial iterations was obtained randomly using a single chain with 200,000 iterations. Convergence diagnosis was conducted using $\mathrm{R}$ software with the Bayesian Output Analysis (BOA) package (Smith, 2005).
The diagnosis proposed by Raftery and Lewis (1992) includes convergence to a stationary distribution and finds the chain size needed to accurately estimate the quantiles of the functions of the parameters. The BOA package user can specify the quantile of interest, the desired degree of accuracy for the estimation of this quantile and the probability of obtaining the desired degree of accuracy.

\section{RESULTS AND DISCUSSION}

The convergence diagnosis using the Raftery and Lewis (1992) method, as implemented by the BOA program, indicated a "burn-in" period and a sample interval smaller than 288 and 36 iterations, respectively, for all parameters. The small "burn-in" period could occur due to the use of (co)variance component estimates obtained previously using Restricted Maximum Likelihood.

If the number of specified iterations is adequate, the a posteriori sample means will be valid estimates of the a posteriori distribution of parameters. The accuracy of these estimates can be verified using the Markov error, which is inversely proportional to the length of the chain. In this study, the length of the chain was 200,000 iterations, and the Markov error was small for the genetic parameters of BWT (Table 1), thus demonstrating the relative accuracy of these estimates. However, although the Markov errors were low for WWT (Table 2), they were greater than those observed for BWT. 
Table 1. Means, standard deviations, Markov errors, medians, modes and high-density intervals of genetic parameters for birth weight.

\begin{tabular}{cccccccc}
\hline & & & & & \multicolumn{2}{c}{ High-density interval } \\
\hline Parameter & Mean & $\begin{array}{c}\text { Standard } \\
\text { deviation }\end{array}$ & Markov error & Median & Mode & Lower limit & Upper limit \\
\hline$\sigma_{d}^{2}$ & 0.10 & 0.03 & 0.003 & 0.10 & 0.09 & 0.04 & 0.17 \\
$\sigma_{e}^{2}$ & 0.18 & 0.01 & 0.002 & 0.18 & 0.19 & 0.14 & 0.21 \\
$\sigma_{p}^{2}$ & 0.44 & 0.05 & 0.006 & 0.44 & 0.43 & 0.33 & 0.53 \\
$\sigma_{d m}$ & -0.07 & 0.05 & 0.006 & -0.07 & -0.08 & -0.15 & 0.03 \\
$\sigma_{m}^{2}$ & 0.15 & 0.04 & 0.006 & 0.16 & 0.16 & 0.05 & 0.23 \\
$h_{d}^{2}$ & 0.24 & 0.07 & 0.008 & 0.23 & 0.20 & 0.12 & 0.38 \\
$h_{m}^{2}$ & 0.34 & 0.07 & 0.009 & 0.36 & 0.36 & 0.21 & 0.47 \\
$r_{d m}$ & -0.23 & 0.15 & 0.022 & -0.27 & -0.33 & -0.44 & 0.12 \\
\hline
\end{tabular}

$\sigma_{d}^{2}=$ direct additive genetic variance; $\quad \sigma_{e}^{2}=$ residual variance; $\quad \sigma_{p}^{2}=$ phenotypic variance; $\quad \sigma_{d m}=$ direct and maternal additive genetic covariance; $\sigma_{m}^{2}=$ maternal additive genetic variance; ${ }^{h_{d}^{2}}=$ direct additive genetic heritability; ${ }^{h_{m}^{2}}=$ maternal additive genetic heritability; $\stackrel{r}{d m}=$ correlation between direct and maternal additive genetic effects.

Table 2. Means, standard deviations, Markov errors, medians, modes and high-density intervals of genetic parameters for weaning weight.

\begin{tabular}{cccccccc}
\hline & \multicolumn{3}{c}{} & & & \multicolumn{2}{c}{ High-density interval } \\
\hline Parameter $^{1}$ & Mean & $\begin{array}{c}\text { Standard } \\
\text { deviation }\end{array}$ & Markov error & Median & Mode & Lower limit & Upper limit \\
\hline$\sigma_{d}^{2}$ & 1.17 & 0.55 & 0.060 & 1.10 & 1.10 & 0.31 & 2.15 \\
$\sigma_{e}^{2}$ & 7.68 & 0.42 & 0.030 & 7.70 & 7.91 & 6.78 & 8.45 \\
$\sigma_{p}^{2}$ & 11.74 & 0.84 & 0.097 & 11.66 & 11.55 & 10.22 & 13.34 \\
$\sigma_{d m}$ & -0.57 & 0.69 & 0.089 & -0.49 & 0.01 & -1.96 & 0.62 \\
$\sigma_{m}^{2}$ & 2.90 & 0.72 & 0.083 & 2.83 & 2.67 & 1.53 & 4.22 \\
$h_{d}^{2}$ & 0.09 & 0.04 & 0.004 & 0.09 & 0.09 & 0.03 & 0.18 \\
$h_{m}^{2}$ & 0.24 & 0.05 & 0.005 & 0.24 & 0.24 & 0.16 & 0.33 \\
$r_{d m}$ & -0.11 & 0.14 & 0.020 & -0.13 & -0.15 & -0.38 & 0.15 \\
\hline
\end{tabular}

${ }^{1}$ see Table 1.

The means, medians and modes of the genetic parameter estimates were similar for BWT (Table 1), as expected for an a posteriori marginal density that follows a normal distribution. Yazdi et al. (1999) also observed similarities between the mean, median and mode for birth weight in the Baluchi breed. However, for WWT (Table 2), this similarity was not observed for some parameters, which was possibly due to a smaller number of observations for the WWT trait.

While the estimate of (co)variance between direct and maternal effects was negative and close to zero for BWT, the high-density interval included both positive and negative values (Table 1). These results are similar to those obtained by Van Wyk et al. (1993) and by Boujenane and Kansari (2002), who reported estimates of -0.05 and -0.01 , respectively. However, these results are unlike those obtained by Maria et al. (1993), who obtained estimates that were negative and close to unity (-0.99). According to Yazdi et al. (1999), because the prenatal growth of lambs occurs before the dam can provide an adequate uterine environment, it is expected that the genetic correlation is not high. 
Never the less, for WWT, an average of -0.57 was observed for the (co)variance estimate, with a wide high-density interval (-1.96 to 0.62$)$, indicating great variability for this estimate, thus corroborating the estimate of 0.60 measured by Van Wyk et al. (1993). However, Boujenane and Kansari (2002) obtained a direct maternal (co)variance of -0.02 .

The antagonism between the direct and maternal additive genetic effects may be due to natural selection. In mammals, dams exert a greater effect than sires on the phenotype of descendants because, in addition to their genetic contribution, they can also influence the offspring through the environment that they provide. Thus, growth traits, especially until weaning, are determined by two genotypes: the genotype of the animal itself (direct genetic effect) and that of the dam (maternal genetic effect). According to Sousa et al. (1999), to increase genetic gain in breeding programs that select traits influenced by the maternal effect, it is necessary to obtain more information on this effect. Heritability can be overestimated if important maternal genetic effects are left out of the models, thereby reducing selection efficiency.

The estimate of direct heritability (Table 1) for BWT corroborates that estimated by Sarmento et al. (2006), who obtained a value of 0.23 in a two-trait analysis. Yazdi et al. (1999) observed lower values for the mean $(0.15)$ and mode $(0.14)$, with smaller high-density intervals ( 0.09 to 0.23$)$ than those found in this study (0.12 to 0.38). Boujenane and Kansari (2002) reported a heritability of 0.05 . The results of this study indicate that there is genetic variability for selection for this trait. However, these different studies show that the results about the heritability of this characteristic are few conclusive and highlight the need for good use of databases with a correct statistical methodology.

The heritability estimated for WWT was lower (0.09) than that estimated for BWT (0.24). Similar results were observed by Sousa et al. (1999) who obtained lower estimates (0.04) at an age of 112 days (weaning) relative to the heritability of birth weight (0.37). Boujenaje and Kansari (2002) and Sousa et al. (2006) also obtained low estimates of heritability (0.06 and 0.11 , respectively) for weaning weight at 90 days of age. However, Lôbo et al. (2006) reported a heritability of 0.56 for weaning weight at 90 days. According to Hanssen et al. (2003), direct heritability generally tends to be greater than maternal heritability for growth traits. Weaning age can influence the heritability of weaning weight. Maria et al. (1993) reported a heritability of 0.34 for weaning weight at 60 days of age and 0.09 for weight at 90 days of age.

A mean maternal heritability of 0.34 was observed for BWT, indicating a strong maternal effect for this trait in lambs, highlighting the importance of maternal effect in sheep. Sarmento et al. (2006) observed a similar value (0.32). The heritability estimated in this study was higher than those obtained by Yazdi et al. (1999), Quesada et al. (2002) and Lôbo et al. (2009), who reported values of $0.14,0.22$ and 0.17, respectively. Boujenane and Kansari (2002) reported an even lower value (0.05), showing that this parameter is still inconclusive.

For WWT, the maternal heritability estimates (Table 2) corroborate those observed by Souza et al. (1999) and Sarmento et al. (2006), who reported values of 0.26 and 0.24 , respectively, for weight at 112 days of age, and by Lôbo et al. (2006), who obtained an estimate of 0.27 for weight at 90 days of age. Riggio et al. (2008) reported a lower estimate $(0.12)$ for weight at 90 days. The maternal heritability for WWT despite being smaller than the heritability of BWT also shows the good influence of maternal effect in sheep at weaning at 90 days old.

In this study, the estimate of the direct additive genetic correlation between BWT and WWT was 0.14 , suggesting a low association between the two traits. This result indicates that selection for both traits should be conducted simultaneously. Simm et al. (2002) observed a value of -0.32 while Hanford et al. (2002) observed a high value (0.84) of genetic correlation. Maria et al. (1993) and Neser et al. (2001) reported values of 0.24 and 0.27 , respectively. Souza et al. (1999) also observed low genetic correlation (0.37) between birth weight and weaning weight, but greater than that obtained in this study.

\section{CONCLUSIONS}

The breeding of Santa Ines sheep for meat production should take into consideration a simultaneous evaluation of birth weight and weaning weight, which are both important growth traits. The maternal heritability obtained in this study indicates that the maternal capacity of Santa Ines sheep has a strong influence on the traits evaluated; therefore, it is necessary to include this effect when considering the improvement of this breed.

\section{ACKNOWLEDGEMENTS}

Thanks to FAPITEC for financing this research and to EMBRAPA/CPATC for their partnership.

\section{REFERENCES}

BARBOSA, L. et al. Estimação de parâmetros genéticos em suínos usando Amostrador de Gibbs. Revista Brasileira de Zootecnia, Viçosa, v. 37, n. 7, p. 1200-1206, 2008.

BOUJENANE, I., KANSARI, J. Estimates of (co) variances due to direct and maternal effects for body 
weights in Timahdite sheep. Animal Science, Midlothian, v. 74, n. 4, p.409-414, 2002.

HANFORD, K. J., VAN VLECK, L. D., SNOWDER, G. D. Estimates of genetics parameters and genetic change for reproduction, weight, and wool characteristics of Columbia sheep. Journal Animal Science, Champaign, v. 80 , n. 12, p.3086-3098, 2002.

HASSEN Y., FUERST-WALTL B., SÖLKNER, J. Genetic parameter estimates for birth weight, weaning weight and average daily gain in pure and crossbred sheep in Ethiopia. Journal of Animal Breeding and Genetics, United Kingdom, v. 120, n. 1, p. 29-38, 2003.

LÔBO, R. N. B. et al. Parâmetros genéticos de características estimadas da curva de crescimento de ovinos da raça Santa Inês. Revista Brasileira Zootecnia, Viçosa, v. 35, n. 3, p. 1012-1019, 2006. (Suplemento)

LÔBO, A. M. B. O. et al. Genetic parameters for growth, reproductive and maternal traits in a multibred meat sheep population. Genetics and Molecular Biology, Ribeirão Preto, v. 32, n. 4, p. 761-770, 2009.

MANIATIS, N., POLLOTT, G. E. The impact of data structure on genetic (co)variance components of early growth in sheep, estimated using an animal model with maternal effects. Journal Animal Science, Champaign, v. 81, n. 1, p. 101-108, 2003.

MARIA, G. A., BOLDMAN, K. G., VAN VLECK, L. D. Estimates of variance due to direct and maternal effects for growth traits of Romanov sheep. Journal Animal Science, Champaign, v. 71, n. 4, p. 845-852, 1993.

NESER, F. W. C., ERASMUS, G. J., VAN WYK, J. B. Genetic parameter estimates for pre-weaning weight traits in Dorper Sheep. Small Ruminants Resource, Little Rock, v. 40, n. 3, p. 197-202, 2001.

RAFTERY, A. E., LEWIS S. How many iterations in the Gibbs sampler? In: BERNARDO J. M.; BERGER J. O.; DAWID A. P.; SMITH A. F. M. (Ed.). Bayesian Statistics. New York: Oxford University Press, 1992. v. 4, p. 763-773.

RIGGIO, V., FINOCCHIARO, R., BISHOP, D. S. C. Genetic parameters for early lamb survival and growth in Scottish Blackface sheep. Journal Animal Science, Champaign, v. 86, n. 8, p. 1758-1764. 2008. trito federal. Revista Brasileira de Zootecnia, Viçosa, v. 31, n. 1, p. 342-349 2002. (Suplemento)

SARMENTO, J. L. R. et al. Estimação de parâmetros genéticos para características de crescimento de ovinos Santa Inês utilizando modelos uni e multicaracterísticas. Arquivo Brasileiro de Medicina Veterinária e Zootecnia, Belo Horizonte, v. 58, n. 4, p. 581-589, 2006

SIMM, G. et al. Responses to selection for lean growth in sheep. Animal Science, Midlothian, v. 74, n. 1, p. $39-50,2002$.

SMITH, B. J. 2005. Bayesian output analysis program (BOA) for MCMC. Avaliable at: http:// www.public-health.uiowa.edu/boa/BOA.pdf. Accessed 18 Feb 2014.

SOUSA, W. H. et al. Estimativas de componentes de (co)variância e herdabilidade direta e materna de pesos corporais em ovinos da raça Santa Inês. Revista Brasileira de Zootecnia, Viçosa, v. 28, n. 6, p. 1252-1262, 1999.

SOUSA, J. E. R. et al. Efeitos genéticos e de ambiente para características de crescimento em ovinos Santa Inês no Estado do Ceará. Revista Ciência Agronômica, Fortaleza, v. 37, n. 3, p. 364-368, 2006.

TORRES, S. E. F. A. et al. Nematódeos de ruminantes em pastagem com diferentes sistemas de pastejo com ovinos e bovinos. Pesquisa Agropecuária Brasileira, Brasilia, v. 44, n. 9, p. 1191-1197, 2009.

Van TASSELL, C. P., Van VLECK, L. D. A manual for use of MTGSAM: A set of FORTRAN programs to apply Gibbs sampling to animal models for variance components estimation (DRAFT). Lincoln, 1985.

Van WYK, J. B., ERASMUS, G. J., KONSTANTINOV, K. V. Variance components and heritability estimates of early growth traits in the Elsenburg Dormer sheep stud. South Africa Journal Animal Science, Hatfield, v. 23, n. 3, p. 72-76, 1993.

YAZDI, M. H. et al. Bayesian analysis of birth weight and litter size in Baluchi sheep using Gibbs Sampling. Journal Animal Science, Champaign, v. 77 , n. 3, p. 533-540, 1999.

QUESADA, M., McMANUS, C., COUTO, F. A. D. Efeitos genéticos e fenotípicos sobre característica de produção e reprodução de ovinos deslanados no dis- 